\title{
Effect of micronutrients foliar supplementation on the production and eminence of plum
}

\section{(Prunus domestica L.)}

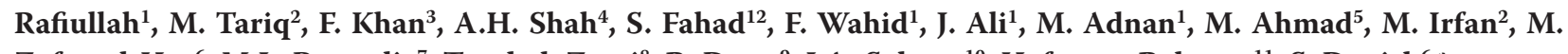
Zafar-ul-Hye $^{6}$, M.L. Battaglia ${ }^{7}$, Tayebeh Zarei ${ }^{8}$, R. Datta ${ }^{9}$, I.A. Saleem ${ }^{10}$, Hafeez-u-Rehman ${ }^{11}$, S. Danish $^{6, *}$

${ }^{1}$ Department of Agriculture, University of Swabi Khyber Pakhtunkhwa, Ambar, Pakistan; ${ }^{2}$ Department of Soil and Environmental Sciences, The University of Agriculture, Peshawar, Pakistan; ${ }^{3}$ Directorate General of Soil and Water Conservation, Peshawar, Khyber Pakhtunkhwa, 25120 Pakistan; ${ }^{4}$ Department of Environmental Sciences, Nanjing University of Information Science and Technology (NUIST), Nanjing, PR China; ${ }^{5}$ Department of Agriculture, Bacha Khan University, Charsadda, Khyber Pakhtunkhwa, Pakistan; ${ }^{6}$ Department of Soil Science, Faculty of Agricultural Sciences and Technology, Bahauddin Zakariya University, Multan, Pakistan; ${ }^{7}$ Department of Animal Science, College of Agriculture and Life Sciences, Cornell University, Ithaca, NY, USA; ${ }^{8}$ Department of Agronomy and Plant Breeding, Yasouj University, Yasouj, Iran; ${ }^{9}$ Department of Geology and Pedology, Faculty of Forestry and Wood Technology, Mendel University in Brno, Brno, Czech Republic; ${ }^{10}$ Soil and Water Testing Laboratory, Mandi Bahauddin, Punjab, Pakistan; ${ }^{11}$ Soil and Water Testing Laboratory, Sialkot, Punjab, Pakistan; ${ }^{12}$ Department of Agronomy, The University of Haripur, Khyber Pakhtunkhwa, Pakistan

*Corresponding Author: S. Danish, Department of Soil Science, Faculty of Agricultural Sciences and Technology, Bahauddin Zakariya University, Multan, Punjab, Pakistan. Email: sd96850@gmail.com

Received: 23 August 2020; Accepted: 22 October 2020; Published: 31 October 2020

(C) 2020 Codon Publications

OPEN ACCESS (c) $\underset{\mathrm{BY}}{\mathrm{NC}(\mathrm{SA}}$

ORIGINAL ARTICLE

\begin{abstract}
Poor soil fertility due to continuous depletion of micronutrients is a major problem for the production of Prunus domestica L. Low level of soil organic matter and calcareous parent material decrease the bioavailability of these micronutrients to plum plants. Thus, less micronutrients uptake resulted in deterioration of plum fruit quality and decreased yield. On the other hand, balance and correct combination of micronutrients used as a foliar has potential to overcome this problem. Foliar application method provides plants a chance for rapid and easy uptake of micronutrients. Therefore, the present research was carried out to select the best combination of micronutrients using foliar method. Aim of the study was to select a balanced combination of micronutrients for better production and improved quality of plum (Prunus domestica L., variety Fazal manai) fruit. Seven treatments in three replications were applied. Our results showed that the quality of fruit was significantly improved through the application of T6 micronutrients consortia. A significant increase in total soluble solids (16\%), fruit yield per tree $(92 \%)$ and fruit size (12\%) validated the effectiveness of treatment T6 $(\mathrm{Zn}+\mathrm{Cu}+\mathrm{Fe}+\mathrm{Mn}+\mathrm{B}=0.5 \%+0.2 \%+$ $0.5 \%+0.5 \%+0.1 \%)$ over control. Application of treatment T6 also enhanced quality attributes, that is, juice acidity $(22 \%)$, juice sugar $(22 \%)$ and juice contents $(16 \%)$, as compared to control. It is concluded that use of treatment T6 as a foliar application is a better approach for significant improvement in quality and yield attributes of plum in micronutrients deficient conditions.
\end{abstract}

Keywords: consortia, foliar application, zinc, iron, boron, copper, plum, quality attributes, yield 


\section{Introduction}

Plum (Prunus domestica L.) is a nutritious fruit, rich in vitamins and minerals. It has great economic importance and is widely grown for profit (Gregory, 1993 and Misra et al. 1986). Orchards of plum are cultivated in different areas of Khyber Pakhtunkhwa based on climatic conditions and variables, that is, quality of water, chill units and value of the market. However, nutritional surveys of plum orchards in Khyber Pakhtunkhwa region indicated a severe deficiency of micronutrients (Muhammad et al. 1995; Tariq et al. 2008 and Bacha et al. 1997).

Deficiency of micronutrients affects the production as well as quality of fruit. The soil of Peshawar, a subdivision in Khyber Pakhtunkhwa province of Pakistan, is rich in organic matter, which is a very important factor for better availability of macro and micronutrients to plants (El-Sheikha, 2016 and Burki, 2000). However, calcareous parent material causes unavailability of micronutrients to plants. So plum orchards in Peshawar produce poor quality fruit with lower yield (Zekri and Obreza, 2003). The nutritional survey report (2016-2017) and Balakrishnan et al. (2000) stated that micronutrient deficiency in Peshawar soil and lack of use of micronutrient fertiliser by local farmers were causing a severe nutritional deficiency in plum fruit. Furthermore, symptoms of nutritional deficiency in plants are an indication of the prevalence of micronutrient deficiency (Belkhodja et al. 1998; Tiwari et al. 2000 and Khattak and Hussain, 2007). Plum orchards with sufficient micronutrients in soil still show young yellowish leaves, indicating that the transfer of nutrients does not meet demands of the plant. Plant nutrient uptake is a serious concern in Khyber Pakhtunkhwa province of Pakistan. Peach, apricot and plum are commonly affected plants with iron (Fe) deficiency (Tariq and Rafiullah 2008-09 and Rehman, 1990). Formation of gum pockets is another common problem in plum, which is due to the deficiency of boron (B) (Shorrocks, 1984, Boaretto et al. 2008 and Saraswathi et al. 1998).

Foliar application of micronutrients could be a better alternative to soil application, since the application of these nutrients to soil may be beyond reach to the deep root system of orchards trees (Ziogas et al. 2020, Bibi et al. 2019, Ahmad et al. 2018 and Hipps and Davies, 2001). Additionally, the foliar application is more valuable because of quick reaction, recovery of nutrient deficiency (Muradi and Godara, 2020 and Samant et al. 2008) and its effectiveness because of boron, manganese (Mn), copper $(\mathrm{Cu}), \mathrm{Fe}$ and zinc $(\mathrm{Zn})$. However, some indigenous studies have suggested the recommended dose and time of foliar application of micronutrients. Saini et al. (2019), Zia et al. (2006) and Stampar et al. (2006) have observed positive effects of foliar application of micronutrients just before flowering and preferably after fruit harvest. Foliar application before flowering is best because application of micronutrients enhances flower formation, fruit set, promotes ripening of fruit and improves fruit quality (Dhillon and Bindra, 1995; Farid et al. 2007 and Sharma et al. 1999). In addition, it also increases fruit firmness and shelf life (Deepa et al. 2008 and Samar et al. 2007).

So far, scientists have documented a large number of works regarding the use of combination of macro- and micronutrients in different fruits. Limited updated literature is available on improvement in yield and quality attributes (total soluble solids [TSS], fruit juice acidity and sugar contents) of plum plants by using micronutrients consortia in calcareous soils. Novelty of the present study is the selection of best micronutrients combination as consortia to fulfill the micronutrients' requirement of plum fruit cultivated in calcareous soils. We hypothesised that foliar application of micronutrients consortia could be beneficial to plum plant especially grown in calcareous soil. In the light of our nutritional survey done on the predominant value of micronutrients in plum trees of Peshawar locality, current study would help in the management of micronutrients of plum orchards in calcareous soils.

\section{Methodology}

\section{Experimental design}

The research was carried out on 14 years old plum (Fazal manani variety) plants orchard at Tarnab Peshawar. For this study, statistical design, randomised complete block (RCBD) with three replications, was used.

\section{Soil characterisation}

Soil samples were collected from the plum orchard, airdried, grinded and then sieved with $2-\mathrm{mm}$ mesh sieve. The important physico-chemical characteristics of the soil determined includes texture (Gee and Budr, 1982), lime (Cottenie, 1980), pH (McLean, 1982), electrical conductivity (EC) (Rhoades, 1982) and organic matter (Nelson and Sommers, 1982). Characterisation of plum orchard's soil (Table 1) showed that textural class of soil was silty clay loam, alkaline in reaction, non-saline and slightly calcareous in nature. The organic matter was found to be medium. Hot water-soluble boron (Sillanpaa, 1982) was assessed by spectrophotometer, while AB-DTPA soil extractable of $\mathrm{Cu}, \mathrm{Mn}, \mathrm{Zn}$ and Fe (Soltanpour, 1985) was analysed by atomic absorption spectrophotometer. Preexperiment characterisation revealed that the concentration of B, $\mathrm{Zn}$ and Fe was highly deficient in the soil of research field (Table 1 ). 
Table 1. Physical and chemical properties of the research field.

\begin{tabular}{lcc} 
Properties & Units & Values \\
\hline Sand & $\%$ & 20.0 \\
Silt & $\%$ & 52.0 \\
Clay & $\%$ & 28.0 \\
Textural class & - & Silty clay loam \\
$\mathrm{pH}_{(1: 5)}$ & - & 7.95 \\
E.C. $_{(1: 5)}$ & $\mathrm{dS} \mathrm{m}^{-1}$ & 0.32 \\
Organic matter & $\%$ & 1.07 \\
Lime & $\%$ & 11.4 \\
AB-DTPA $\mathrm{Zn}$ & $\mathrm{ppm}$ & 0.49 \\
AB-DTPA Cu & $\mathrm{ppm}$ & 1.71 \\
AB-DTPA Fe & $\mathrm{ppm}$ & 0.37 \\
AB-DTPA Mn & $\mathrm{ppm}$ & 2.59 \\
Hot water-soluble B & $\mathrm{ppm}$ & 0.48 \\
\hline
\end{tabular}

\section{Treatment plan}

The following six treatments were applied in three replications: $\mathrm{T} 1=$ control (without foliar spray); $\mathrm{T} 2=\mathrm{Zn}$ $(0.5 \%)$ applied as $\mathrm{ZnSO}_{4}$; $\mathrm{T} 3=\mathrm{Zn}+\mathrm{Cu}(0.5 \%+0.25 \%)$ applied as $\mathrm{ZnSO}_{4}$ and $\mathrm{CuSO}_{4} ; \mathrm{T} 4=\mathrm{Zn}+\mathrm{Cu}+\mathrm{Fe}(0.5 \%+$ $0.25 \%+0.5 \%)$ applied as $\mathrm{ZnSO}_{4}+\mathrm{CuSO}_{4}+\mathrm{FeSO}_{4}$; $\mathrm{T} 5=$ $\mathrm{Zn}+\mathrm{Cu}+\mathrm{Fe}+\mathrm{Mn}(0.5 \%+0.25 \%+0.5 \%+0.5 \%)$ applied as $\mathrm{ZnSO}_{4}+\mathrm{CuSO}_{4}+\mathrm{FeSO}_{4}+\mathrm{MnSO}_{4}$, and $\mathrm{T} 6=\mathrm{Zn}+\mathrm{Cu}+$ $\mathrm{Fe}+\mathrm{Mn}+\mathrm{B}(0.5 \%+0.2 \%+0.5 \%+0.5 \%+0.1 \%)$ applied as $\mathrm{ZnSO}_{4}+\mathrm{CuSO}_{4}+\mathrm{FeSO}_{4}+\mathrm{MnSO}_{4}+\mathrm{Na}_{2} \mathrm{~B}_{4} \mathrm{O}_{7} \cdot 10 \mathrm{H}_{2} \mathrm{O}$.

\section{Fertiliser application}

Nitrogen $(\mathrm{N})$, phosphorus $(\mathrm{P})$ and potash $(\mathrm{K}), 150,100$ and $100 \mathrm{~kg} \mathrm{ha}^{-1}$, respectively, were applied under the canopy of each tree. The reserved area was $65 \mathrm{~cm}$ around each tree where basal dose was applied and irrigated. The nutrients were applied twice within 20 days interval, as the leaves and fruit developed at the start of spring season. Application of primary micronutrients was done to all experimental trees at recommended basal doses. Foliar sprays were applied twice during the growth season. Foliar sprays were applied in March-April 2017.

\section{Solution preparation of foliar supplementation}

For this research work, solution of foliar supplementation was prepared from the commercial micronutrients available in the market. These micronutrients were applied by using their chemical formulas. To supplement micronutrients as a foliar application, first the canopy of each tree was completely witted with water assuming the total volume on whole tree.

\section{Analysis of fruit quality attributes}

In this research work, different chemical properties were checked according to the method described by the Association of Official Analytical Chemists (AOAC; 1990); these were sugars (reducing, non-reducing), $\mathrm{pH}$ of fruit juice, acidity and TSS. Before and after inversion with invertase, polarimetric method was used to determine the sugars in plum fruit, $\mathrm{pH}$ meter was used for the $\mathrm{pH}$ of fruit juice, volume of juice were calculated by a cylinder, TSS of fruit was calculated by refractometer, and acidity by titration of a $25-\mathrm{mL}$ aliquot of juice using $0.25 \mathrm{~N} \mathrm{NaOH}$ to an end point of $\mathrm{pH}$ by an autotitrator. While fruit size was calculated using vernier caliper, volume of the plum fruit was calculated using eight plum fruit selected randomly by water displacement method (Maurer and Taylor, 1999, Wer and LiuWengeng 1998 and Sing et al. (2005).

\section{Statistical analyses}

The overall data of this experiment were analysed statistically using analysis of variance (ANOVA). Difference between the treatments were evaluated at $\mathrm{p} \leq 0.05$ by Fisher's least significant difference (LSD) test of significance (Steel et al. 1997) using Origin software (OriginPro version 2020b, Origin Lab Cooperation, Northampton, MA, USA) and SPSS (version 20).

\section{Results and Discussion}

\section{Fruit number}

Application of treatments significantly affects the number of fruit per plant (NFPT) (Figure 1A). Treatment T6 differed significantly from control for NFPT in Prunus domestica L fruit. No significant change in NFPT was noted where treatments T2, T3, T4 and T5 were applied over control (Figure 1B). Pearson's correlation showed that a significant positive correlation existed between NFPT, yield of fruit per tree (YFPT) and juice contents (JC) (Figure 8). Maximum increase of $40.94 \%$ in NFPT was noted in T6 treatment over control. These results are in line with the earlier works of Arvind and Ganesh (1996) and Sharma et al. (1991).

\section{Fruit size}

Effect of treatments was significant on fruit size (FS). Results showed that application of T6 treatment was significant as compared to control for improving fruit size (Figure 2A). No significant change in fruit size was noted where treatments T2, T3, T4 and T5 were applied over 
(A)

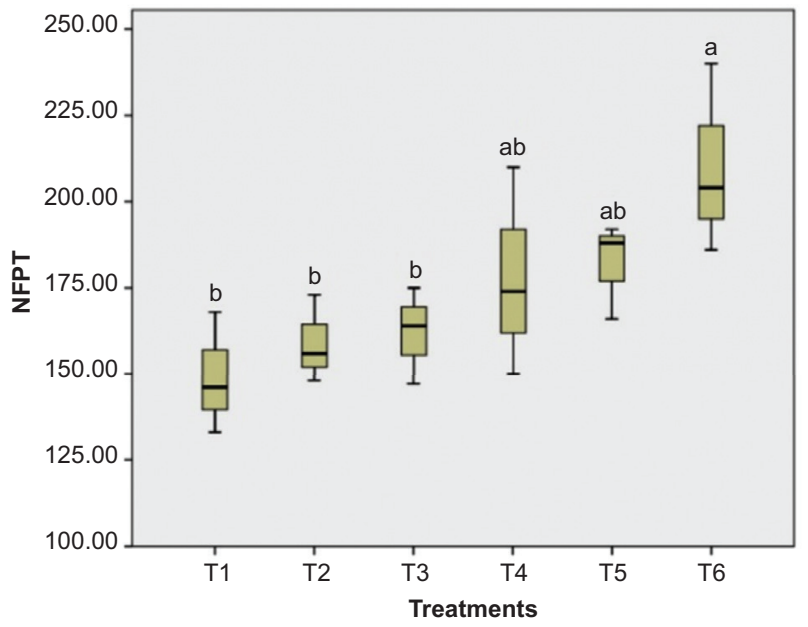

(B)

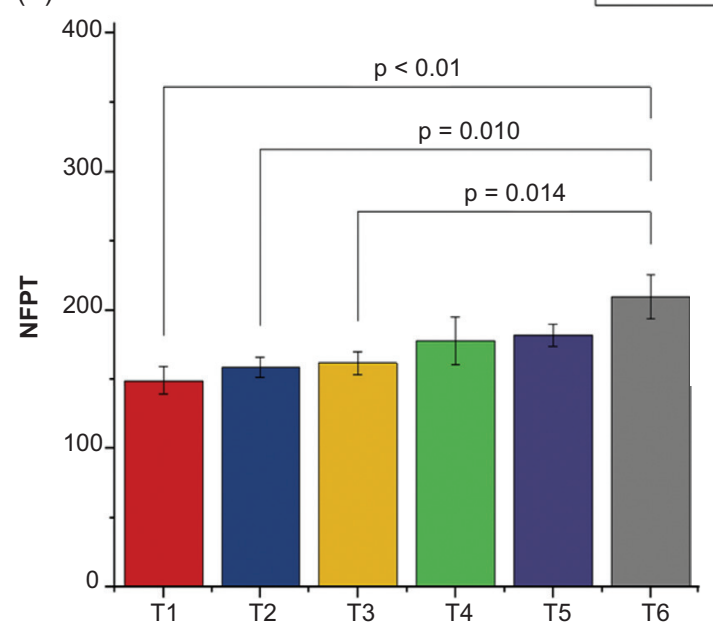

Figure 1. Effect of treatments on number of fruit per plant (NFPT) of Prunus domestica L. Different letters show significant difference compared with Fisher's LSD, $p \leq 0.05$.

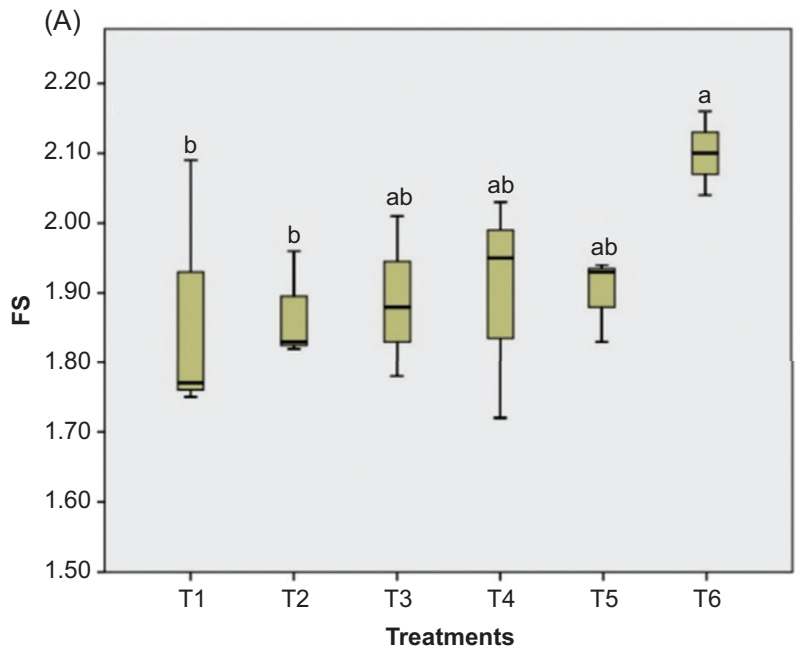

(B)

Fisher LSD $p<0.05$

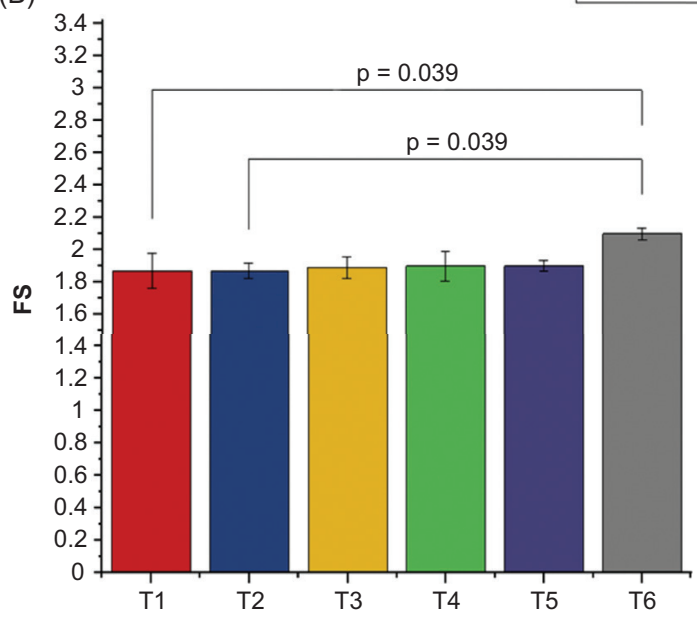

Figure 2. Effect of treatments on fruit size (cm) of Prunus domestica L. Different letters show significant difference compared with Fisher's LSD, $p \leq 0.05$. FS, Fruit size.

control (Figure 2B). Pearson's correlation showed that a significant positive correlation existed between FS, juice sugar contents (JSu) and JC (Figure 8). Maximum increase of $12.30 \%$ in fruit size was noted in $\mathrm{T} 6$ treatment as compared to control. The results were in line with that of Arvind and Ganesh (1996). Moreover, results also indicated that probably boron was transferred to fruit, thereby correcting the deficiency symptoms, as fruit size increased in leaves that had received boron as a foliar supplementation. Similarly, Shorrocks (1984) found in his research work that deficiency of boron was suspected based on leaf symptoms and should be confirmed by fruit symptoms.

\section{Fruit yield per tree}

Application of treatments significantly affects the fruit yield per tree. Treatments T5 and T6 remained significant over control (Figure 3A) for improving YFPT in Prunus domestica L. No significant change in YFPT was noted where treatments T2, T3 and T4 were applied over control (Figure 3B). Pearson's correlation showed that a significant positive correlation existed between YFPT, JSu and JC (Figure 8). Maximum increase of $92.22 \%$ in YFPT was noted in T6 treatment over control. The combination of boron in spray mixture increases significantly the production of plum, as the number and size of fruit also 

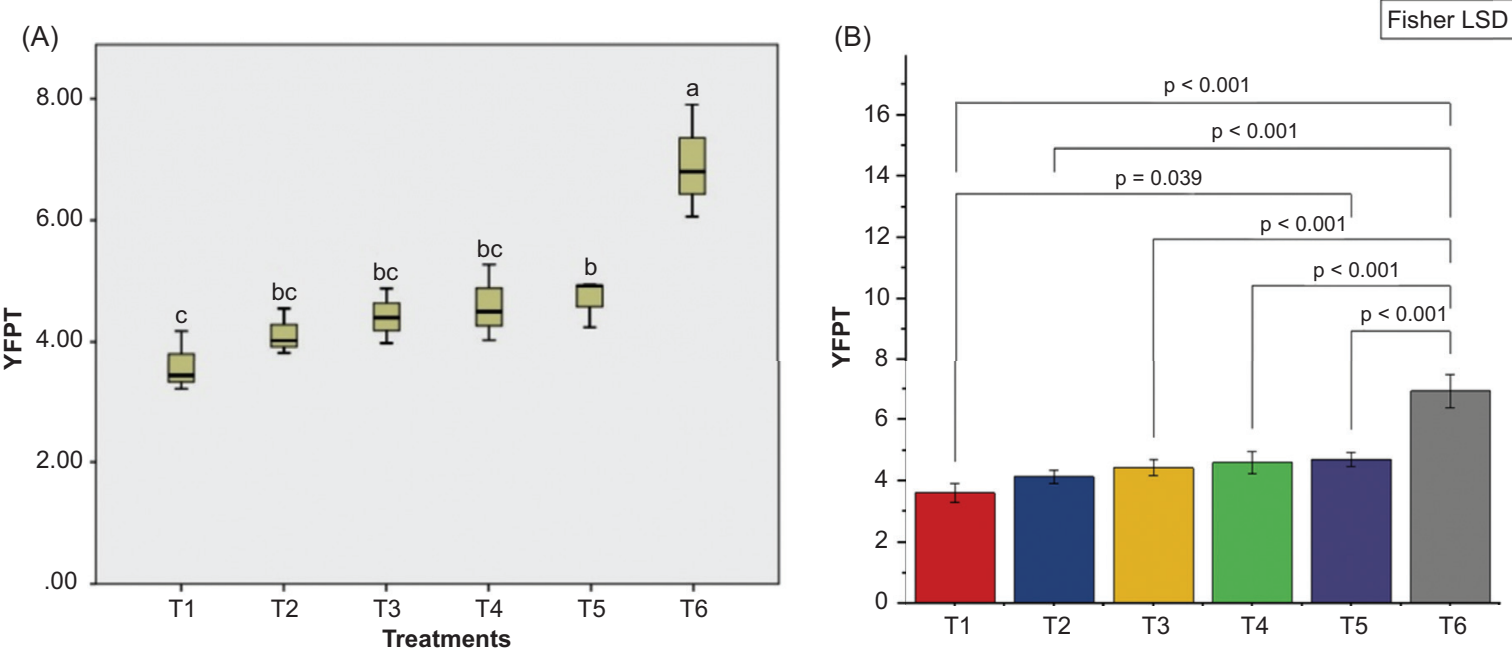

Figure 3. Effect of treatments on fruit yield $\left(\mathrm{kg} \mathrm{plant}^{-1}\right)$ of Prunus domestica L. Different letters show significant difference compared with Fisher's LSD, $\mathrm{p} \leq 0.05$.

increased significantly with such a combination, which results in more production. Similar results were found by Dhillon and Bindra (1995), Upreti et al (1996) and Bose et al. (1994). As was found by Garcia et al. (1984) that fruit let drop decreases with increased concentration of $\mathrm{Mn}$ and $\mathrm{Zn}$ in plant leaves, while a significant increase in formation of flowers increases fruit numbers, fruit weight and size of fruit only because of the foliar supplementation of boron content (Farid et al. 2007). However, the lower yield of plum fruit not only depends on nutritional requirements but also on many other factors. In general, yield of plum fruit was very low in the experimental year of 2009 throughout the Peshawar valley. Probably the chilling requirements of plum orchards were not fulfilled in this year (personnel communications with plum growers), resulting in lower or no yield in the Peshawar valley.

(A)

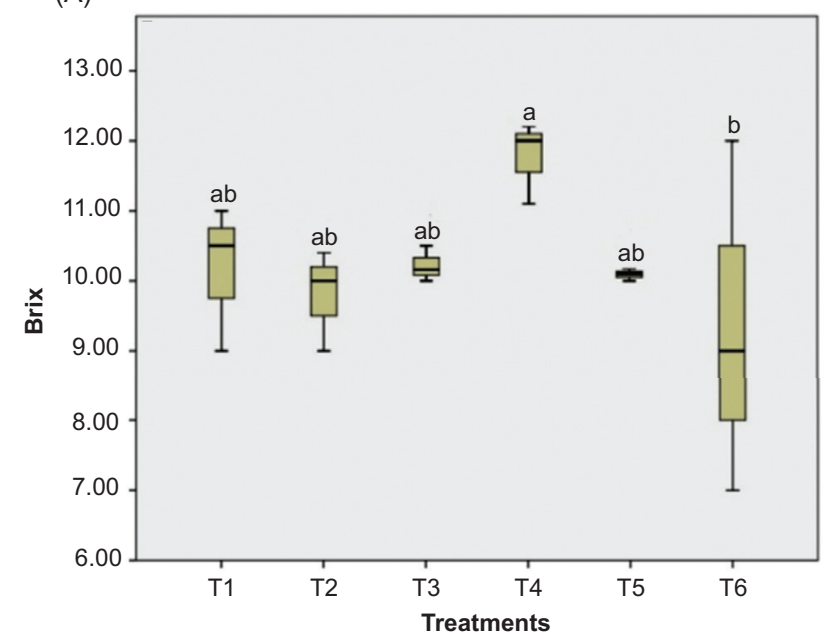

\section{Total soluble solid}

Application of treatments significantly affects TSS. Treatment T4 differed significantly from control for TSS in Prunus domestica L. fruit (Figure 4A). No significant change in TSS was noted where treatments T2, T3, T5 and T6 were applied over control (Figure 4B). Pearson's correlation showed that no significant correlation existed between TSS and any other attribute (Figure 8). Maximum increase of $15.74 \%$ in fruit size was noted in T4 treatment over control. The results are in line with that of Dhillon and Bindra (1995) and Arora et al. (1992). Micronutrients increase the TSS of plum fruit, beside it also depends on the agronomic practices of plum orchards. As McGlasson et al. (2004) have reported that the highest TSS levels were achieved in stone fruit

(B)

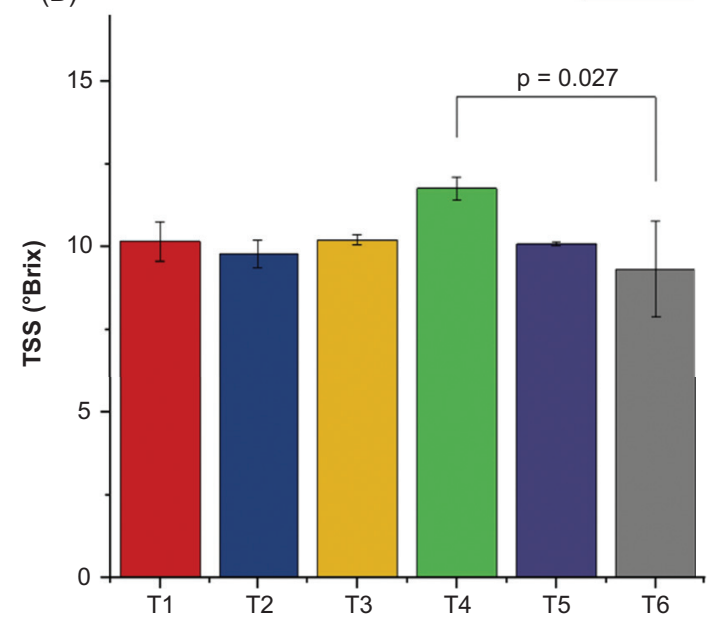

Figure 4. Effect of treatments on total soluble solids (Brix) of Prunus domestica L. Different letters show significant difference compared with Fisher's LSD, $\mathrm{p} \leq 0.05$. 
by leaving these to ripen and completing its shelf life on trees. Similarly, water requirement and its irrigation scheduling (Boland et al. 1993), distribution of light in the canopy of trees (Day, 1997; George et al. 1994) and all other processes change the level of sugar and TSS of plum fruit.

\section{Juice acidity}

Application of treatments significantly affects juice acidity (JA). Treatments T6 and T5 differed significantly from control for JA in Prunus domestica L. fruit (Figure 5A). No significant change in JA was noted where treatments T2, T3 and T4 were applied over control for JA (Figure $5 B)$. Maximum increase of $21.74 \%$ in JA was noted in treatments T6 and T5 over control for JA. Ram and Bose (2000), Abadia et al. (2000) and Tariq et al. (2007) have described non-significant differences in the acidity of mandarin juice and sweet orange juice, respectively, with the foliar sprays of micronutrients. This is not a good evidence that the acidity of plum fruit was increased. The results are contrary to those reported in literature for various plum cultivars (Družić et al. 2007 and Saatci and Mur (2000); perhaps this was due to improper maturity of fruit at harvest, or may be the test plum variety genetically contains high percentage of acidity.

\section{Juice sugar}

Application of treatments significantly affects the juice sugar contents (JSu) of fruit. Treatment T6 differed significantly from control for JSu in Prunus domestica L. fruit (Figure 6A). No significant change in JSu was noted where treatments T2, T3, T4 and T5 were applied over control (Figure 6B). Maximum increase of $21.60 \%$ in JSu was noted in $\mathrm{T} 6$ treatment over control. These results are consistent with the research experiment of Arvind and Ganesh (1996), who reported that percentage sugar was significantly increased due to applied boron as a foliar spray.

\section{Juice content}

Application of treatments significantly affects juice contents (JC). Treatment T6 differed significantly from control for JC in Prunus domestica L. fruit (Figure 7A). No significant change in JC was noted where treatments $\mathrm{T} 2$, T3, T4 and T5 were applied over control (Figure 7B). Maximum increase of $15.61 \%$ in JC was noted in T6 treatment over control. Similarly, its concentration increased due to the addition of boron with other micronutrients, also reported by Ram and Bose (2000) and Awasthi and Upadhayay (1996). The overall results indicated that the foliar supplementation of micronutrients have inconstant effects on the percentage of juice in plum fruit. The TSS, fruit acidity, juice $\mathrm{pH}$ and non-reducing sugar level were found non-significant by the foliar supplementation of micronutrients. The same trend was found by Mann et al. (1985), who reported that citrus fruit quality was found non-significant by foliar supplementation of micronutrients. While other parameters, like percentage of juice and reducing sugar, were significantly affected by foliar supplementation of micronutrients, these results demonstrated that the entire nutrient had a different role on the quality of plum fruit under experimental conditions .
(A)

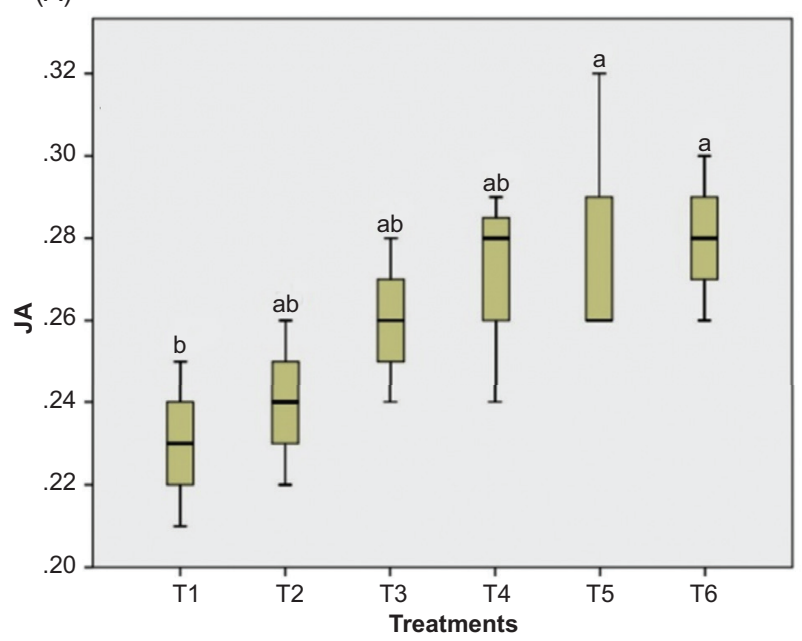

(B)

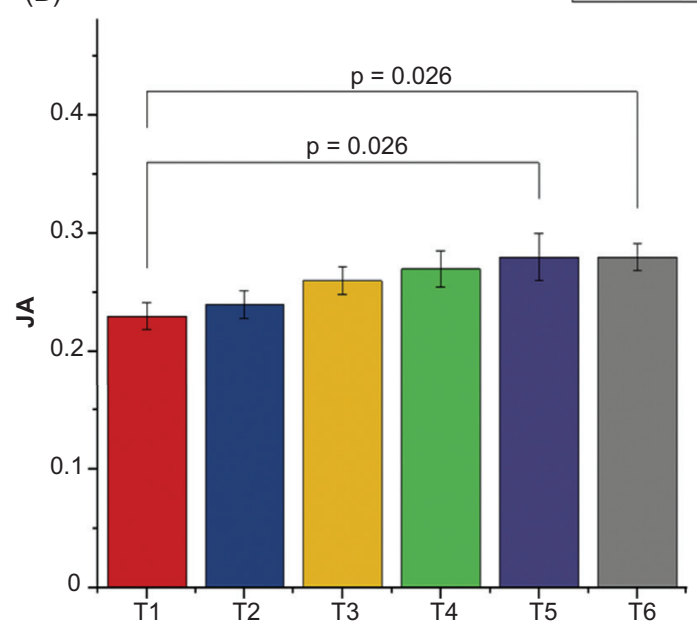

Figure 5. Effect of treatments on juice acidity (JA) of Prunus domestica L. Different letters show significant difference compared with Fisher's LSD, $\mathrm{p} \leq \mathbf{0 . 0 5}$. 

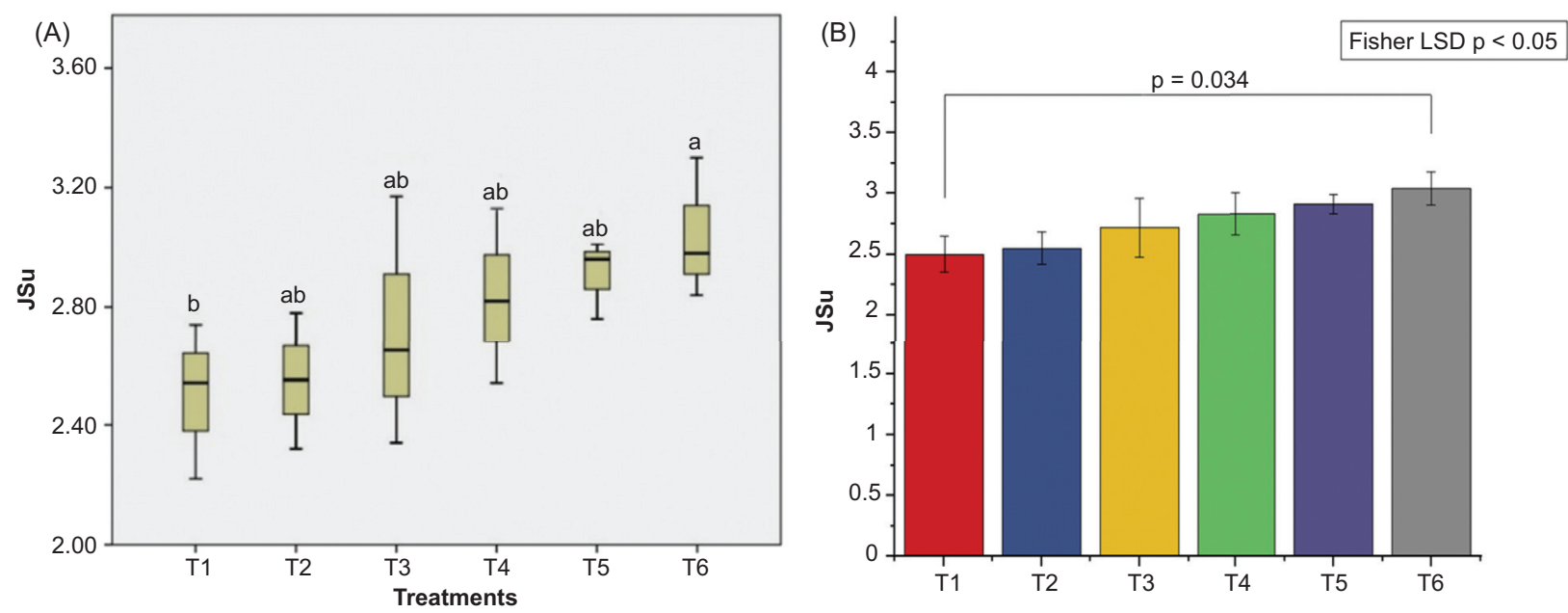

Figure 6. Effect of treatments on juice sugar content (JSu) of Prunus domestica L. Different letters show significant difference compared with Fisher's LSD, $p \leq 0.05$.
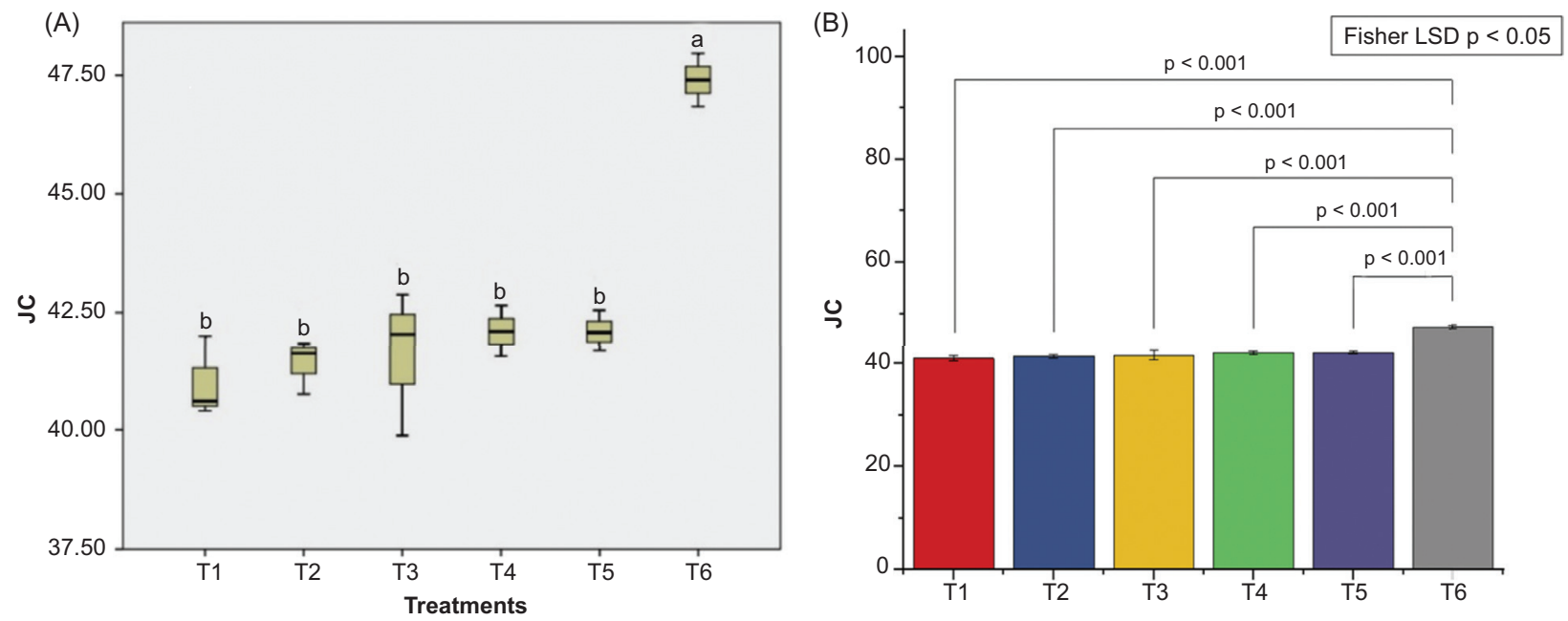

Figure 7. Effect of treatments on juice content (\%) of Prunus domestica L. Different letters show significant difference compared with Fisher's LSD, $p \leq 0.05$. JC, juice content.

\section{Conclusion}

In conclusion, application of treatment T6 ( $\mathrm{Zn} 0.5 \%+$ $\mathrm{Cu} 0.2 \%+\mathrm{Fe} 0.5 \%+\mathrm{Mn} 0.5 \%+\mathrm{B} 0.1 \%$ ) has potential to improve yield attributes of plum, that is, fruit production, and number, size and volume of fruit, especially in calcareous soils. Foliar application of micronutrients consortia $(\mathrm{Zn} 0.5 \%+\mathrm{Cu} 0.2 \%+\mathrm{Fe} 0.5 \%+\mathrm{Mn} 0.5 \%+\mathrm{B} 0.1 \%)$ is an efficacious method to improve the quality indices of plum fruit in calcareous soils. However, more investigations are suggested at field levels to investigate more efficacious and balance use of micronutrients consortia for improving quality and yield attributes in plum fruit.

\section{References}

Abadia, J., Tagliavini, M., Grasa, R., Belkhodja, R., Abadía, A., Sanz, M., Faria, E.A., Tsipouridis, C. and Marangoni, B., 2000. Using the flower $\mathrm{Fe}$ concentration for estimating chlorosis status in fruit tree orchards: a summary report. Journal of Plant Nutrition 23(11-12): 2023-2033. https://doi.org/10.1080/0190 4160009382162

Ahmad, I., Bibi, F., Bakhsh, A., Ullah, H., Danish, S., Asif-urRehman, 2018. Assessment of various levels of potassium citrate and sucrose along with boric acid on quality and yield of Sufaid Chaunsa. International Journal of Biosciences 13: 188-195. https://doi.org/10.12692/ijb/13.1.188-195 
Arora, C.L., Srar, M.S. and Dhatt, A.S., 1992. Secondary and micronutrient status of pear orchards in Punjab. Indian Journal of Horticulture 49(2): 150-154.

Association of Official Analytical Chemists (AOAC), 1990. Official methods of analysis. 15th ed. AOAC, Washington, DC.

Arvind, U. and Ganesh K. 1996. Effect of mineral nutrient sprays on yield and quality of litchi fruits (Litchi chinensis sonn.) cv. Rose Scented. Ind. J. Hort. 53(2): (http://www.indianjournals.com). Accessed on 12/29/2009.

Awasthi, R.P. and Upadhayay, S.K., 1996. Correlation and regression analysis of nutrient status in soil and yield of starking delicious apple. Indian Journal of Horticulture 53(2): 93-96.

Bacha, M.A., Sabbah, S.M. and El-Hamady, M.A., 1997. Effect of foliar application of iron, zinc and manganese on yield, berry quality and leaf mineral composition Thompson seedless and Roomy red grape cultivars. Alexandria Journal of Agricultural Research (Egypt) 9(1): 127-140.

Balakrishnan, K., Rajendran, C. and Kulandaivelu, G., 2000. Differential responses of iron, magnesium, and zinc deficiency on pigment composition, nutrient content, photosynthetic activity in tropical fruit crops. Photosynthetica 38(3): 477-479. https://doi.org/10.1023/A:1010958512210

Belkhodja, R., Morales, F., Sanz, M., Abadía, A. and Abadía, J., 1998. Iron deficiency in peach trees: effects on leaf chlorophyll and nutrient concentrations in flowers and leaves. Plant and Soil 203(2): 257-268. https://doi.org/10.1023/A:1004373202458

Bibi, F., Ahmad, I., Bakhsh, A., Kiran, S., Danish, S., Ullah, H., 2019. Effect of Foliar Application of Boron with Calcium and Potassium on Quality and Yield of Mango cv. Summer Bahisht (SB) Chaunsa. Open Agriculture 4: 98-106. https://doi.org/10.1515/ opag-2019-0009

Boaretto, R.M., Quaggio, J.A., de Assis Alves Mourão Filho, F., Giné, M.F. and Boaretto, A.E., 2008. Absorption and mobility of boron in young citrus plants. Communications in Soil Science and Plant Analysis 39(17-18): 2501-2514. https://doi. org/10.1080/00103620802358383

Boland, A.M., Mitchell, P.D., Jerie, P.H. and Goodwin, I., 1993. The effect of regulated deficit irrigation on tree water use and growth of peach. Journal of Horticultural Science 68(2): 261-274. https://doi.org/10.1080/00221589.1993.11516351

Bose, P.C., Singhvi, N.R. and Dutta, R.K., 1994. Effect of micronutrients on yield and yield attributes of mulberry (Morus alba). Indian Journal of Agronomy 39(1): 97-99.

Burki, F.N., 2000. Micronutrient status of apple orchards in Quetta valley. Library, Sindh Agriculture University, Tandojam, 86 p.

Cottenie, A., 1980. Soil and plant testing as basis for fertilizer recommendations. Food and Agriculture Organization of the United Nation. FAO Soils Bulletin 38(2):64.

Day, K.R., 1997. Orchard factors affecting postharvest stone fruit quality. Hort Science 32(5): 820-823. https://doi.org/10.21273/ HORTSCI.32.5.820

Dhillon, W.S. and Bindra, A.S., 1995. Effect of micro-nutrient sprays on the yield and quality of "Perlette"grapes. Indian Journal of Horticulture 52(1): 27-30.

Družić, J., Voća, S., Čmelik, Z., Dobričević, N., Duralija, B. and Skendrović Babojelić, M., 2007. Fruit quality of plum cultivars
"Elena"and "Bistrica". Agriculturae Conspectus Scientificus 72(4): 307-310.

Deepa, S., N.K. Mishra., A.K. Singh and R.L. Lal. 2008. Effect of micronutrients on fruit yield and quality during storage in ber cv. Umran under ambient conditions Ind. J. Hort. 65(4): (http//www.indianjournals.com). Accessed on 1/21/2010

El-Sheikha, A.F., 2016. Mixing manure with chemical fertilizers, why? And what is after. Nutrition and Food Technology 2: 1-5. https://doi.org/10.16966/2470-6086.112

Farid, A.T.M., Halder, N.K. and Shahjahan, M., 2007. Effect of boron for correcting the deformed shape and size in Jackfruit. Indian Journal of Horticulture 64(2): 144-149.

Garcia, A., Haydar, N.E. and Ferrer, C., 1984. Influence of Zn and $\mathrm{Mn}$ on the physiological behavior and yields of Valencia oranges. Center Agricola. Instt. Superior Agricola Ciego de Avila Cuba 10: $57-58$.

Gee, G.W. and Budr, J.W., 1982. Particle size analysis. In: Klute, A. (ed.) Methods of soil analysis. Physical and mineralogical prosperities,Part I, 2nd ed. Agron. 9 American Society of Agronomy, Madison, WI, pp. 383-411.

George, A.P., Nissen, R.J. and Campbell, J.A., 1994. Effects of paclobutrazol on growth and yield of low chill peaches in tropical Australia. Acta Horticulturae 409: 109-117. https://doi. org/10.17660/ActaHortic.1995.409.11

Grasa, R., Claveria, I., Paniagua, M.P., Abadia, J. and Abadia, A., 2006. Impact of iron chlorosis on macro and micronutrient budgets in peach. Acta Hoticulture 721: 99-104. https://doi. org/10.17660/ActaHortic.2006.721.11

Gregory, J.F., 1993. Ascorbic acid bioavailability in foods and supplements. Nutrition Reviews 51(10):301-303. https://doi. org/10.1111/j.1753-4887.1993.tb03059.x

Hipps, N.A. and Davies, M.J., 2001. Effects of foliar zinc applications at different times in the growing season on tissue zinc concentration, fruit set, yield and grade out of culinary apple trees. In: Neilsen, D., Fallahi, B., Neilsen, G. and Peryea, F. (eds.) VI International Symposium on Mineral Nutrition of Deciduous Fruit Crops, 30 October 2001, Penticon, BC, Canada, ISHS Acta Holticulturae No. 564, ISHA, Belgium.

Khattak, R.A. and Hussain, Z., 2007. Evaluation of soil fertility status and nutrition of orchards. Soil \& Environment 26(1): 22-32.

Mann, M.S., Josan, J.S., Chohan, G.S. and Vij, V.K., 1985. Effect of foliar application of micronutrients on leaf composition, fruit yield and quality of sweet orange (Citrus Sinensis Osbeck) Cv. Blood Red. Indian Journal of Horticulture 42 (1 and 2): 45-49.

Maurer, M.A. and Taylor, K.C., 1999. Effect of foliar boron sprays on yield and fruit quality of naval oranges. Available at: http//ag.arizona.edu/pubs/crops/az1138. Accessed on 15 November 2006.

McGlasson, W.B., Rath, A.C. and Lengendre, L., 2004. Pre-harvest application of aminoethovinylglycine (AVG) modifies harvest maturity and cool storage life of "Artic Snow" nectarines. Postharvest Biology and Technology 36:93-102. https://doi. org/10.1016/j.postharvbio.2004.10.006

McLean, E.O., 1982. Soil pH and lime requirement. In: Page, A.L., Miller, M.H. and Keeny D.R. (eds.) Methods of soil analysis chemical and microbiological prosperities, Part II, Vol. 9 Agronomy, 2nd ed., American Society of Agronomy, Madison, WI, pp. 209-223. 
Misra, R.S., Tawari, J.P. and Joshi, K.R., 1986. Effect of IBA, boron and catechol on the rooting on commercial cultivars of plum grown in UP hills. Progressive Horticulture Uttar pradesh, India.

More, S.D. and Kausadikar, H.K., 2006. Soil and leaf nutrients norms for sweet orange (Citrus Sinensis) grown in Marathwada region of Maharashtra. In: 18th World Congress of Soil Science, PA.

Muhammad, W., Shah, S.M. and Iqbal, M., 1995. Nutritional status of deciduous orchards (plums). Sarhad Journal of Agriculture 11(4):223-226.

Muradi, B. and Godara, A.K., 2020. Effect of foliar fertilization of boron, zinc and iron on fruit quality and leaf nutrients content of peach $\mathrm{cv}$. Shan-e-Punjab. Current Journal of Applied Science and Technology 39(1): 43-51. https://doi.org/10.9734/cjast/2020/v39i130479

Nelson, D.W. and Sommer, L.E., 1982. Total carbon and organic matter. In: Page, A.L., Miller, M.H. and Kenny, D.R. (eds.) Methods of soil analysis chemical and microbiological prosperities, Part II, 2nd ed., Vol. 9 Agronomy, American Society of AgronomyInc., Madison, WI, pp. 539-577.

Plich, H. and Wojcik, P., 1999. The effect of calcium and boron foliar application on postharvest plum fruit quality. In: International Symposium on Foliar Nutrition of Perennial Fruit Plants, ISHS Acta Horticulture No. 594, ISHA, Belgium.

Porter, S.R., Spindler, S.C. and Widdowson, A.E., 1981. An improved automated colorimetric method for the determination of boron in extracts of soils, soil-less peat based compost, plant materials and hydroponics' solutions with Azomethine- $\mathrm{H}$. Communications in Soil Science and Plant Analysis 12: 461-473. https://doi.org/10.1080/00103628109367166

Ram, R.A. and Bose, T.K., 2000. Effect of foliar application of magnesium and micro nutrients on growth, yield and fruit quality of mandarin orange (Citrus reticulate). Indian Journal of Horticulture 57(3): 215-220.

Rehman, H., 1990. Survey of the fruit plants for nutrient-elements content and planning of fertilizer research programme. Annual Report, Directorate of Soil and Plant Nutrition. Agriculture Research Institute Tarnab, Peshawar, Pakistan.

Rhoades, J.D., 1982. Cation exchange capacity. In: Page, A.L., Miller, M.H. and Keeny, D.R. (eds.) Methods of soil analysis chemical and microbiological prosperities, Part II, 2nd ed., Vol. 9. Agronomy. American Society of Agronomy, Madison, WI, pp. 149-157.

Saatci, N. and Mur, B.Y., 2000. Relationships between the concentrations of iron, macro and micronutrients in satsuma mandarine leaves (Citrus reticulata Blanco). In: 9th International Symposium on Iron Nutrition and Interactions in Plants, Stuttgart, Germany, 20-25 July 1997. Journal of Plant Nutrition 23(11-12): 17451750. https://doi.org/10.1080/01904160009382138

Saini, H., Sourabh, V. and Saini, P., 2019. Differential responses of $\mathrm{Fe}, \mathrm{Zn}, \mathrm{B}, \mathrm{Cu}$ and $\mathrm{Mg}$ on growth and quality attributes of fruit crops. Journal of Pharmacognosy and Phytochemistry 8(5): 1-5.

Samant, D., Mishra, N.K., Singh, A.K. and Lal, R.L., 2008. Effect of micronutrient sprays on fruit yield and quality during storage in ber cv. Umran under ambient conditions. Indian Journal of Horticulture 65(4): 399-404.

Samar, S.M., Shahabian, M., Fallahi, E., Davoodi, M.H., Bagheri, Y.R. and Noorgholipoor, F., 2007. Iron deficiency of apple tree as affected by increasing soil available phosphorous. Journal of Plant Nutrition 30(1): 1-7. https://doi. org/10.1080/01904160601054742

Saraswathi, T., Thangaraj, T., Azhakiamanavalan, A.R.S. and Balakrishanamurthy, G., 1998. Effect of micronutrients on the yield and quality of mandarin orange (citrus reticulate L.). South Indian Journal of Horticulture 46: 128-131.

Sharma, R.K., Ram, K. and Thakur, S., 1991. Effect of foliar feeding of potassium, calcium and zinc on the yield and quality of guava. Indian Journal of Horticulture 48(4): 312-314.

Sharma, Y.M., Rathore, G.S. and Jesani, J.C., 1999. Effect of soil and foliar application of zinc and copper on yield and fruit quality of seedless lemon (Citrus lemon L.). Indian Journal of Agricultural Sciences 69:236-238.

Shorrocks, V.M., 1984. Boron deficiency and its prevention and cure. Borax Holdings Limited, Borax House, Carlisle Place, London, England.

Sillanpaa, M., 1982. Micronutrient and nutrient status of soil. A global study. FAO Soil Bulletin. No. 48. Rome.

Stampar, F., Hudina, M., Usenik, V., Sturm, K., Veberic, R. and Veber, G., 2006. Experience with foliar nutrition in apple orchard. International Symposium on Foliar Nutrition of Perennial Fruit Plants. ISHS Acta Horticulturae 594: 547-552. https://doi. org/10.17660/ActaHortic.2002.594.72

Steel, R.G.D., Torrie, J.H. and Dickey, D.A., 1997. Principles and procedures of statistics. A biometrical approach. 3rded. McGraw Hill Companies, Inc., New York.

Tariq, M., and Rafiullah 2008-09. Micronutrients studies for sustainable plum productivity in Peshawar valley. Annual Report. Submitted to HEC-AUP.

Tariq, M., Shah, Z. and Ali, A., 2008. Micronutrients status of plum orchards in Peshawar valley. Soil \& Environment 27(2): 223-227.

Tariq, M., Sharif, M., Shah, Z. and Khan, R., 2007. Effect of foliar application of micronutrients on the yield and quality of sweet orange (Citrus sinensis L.). Pakistan Journal of Biological Sciences 10(11): 1823-1828. https://doi.org/10.3923/pjbs.2007.1823.1828

Tiwari, J.P., Mishra, N.K., Mishra, D.S., Bisen, B., Singh, Y.P. and Rai, R., 2000. Nutrient requirement for subtropical peaches and pear for Uttaranchal. International Society for Horticultural Science 662: 199-203. https://doi.org/10.17660/ActaHortic.2004.662.27

Upreti, A. and Kumar, G., 1996. Effect of mineral nutrient sprays on yield and quality of litchi fruits (Litchi chinensis sonn.) cv. Rose Scented. Indian Journal of Horticulture 53(2): 121-124.

Wer, W. and LiuWengeng, L., 1998. Studies on relationship between fruit yield, quality and microelements in leaves of citrus. Journal of Southwest Agricultural University 20: 198-202.

Zia, M.J, Ahmad, R., Khaliq, I., Ahmad, A. and Irshad, M., 2006. Micronutrient status and management in orchard soil: applied aspects. Soil \& Environment 25(1): 6-16.

Zekri, M., \& Obreza, T. A. (2003). Macronutrient deficiency in citrus: Nitrogen, Phosphorus and Potassium. University of Florida, Institute for Food and Agricultural Sciences, pp. 2-3.

Ziogas, V., Michailidis, M., Karagiannis, E., Tanou, G. and Molassiotis, A., 2020. Manipulating fruit quality through foliar nutrition.In: Srivastava, A.K. and $\mathrm{Hu}, \mathrm{C}$. (eds.) Fruit crops. Elsevier, Cambridge, MA, pp. 401-417. 